\title{
A miscellany for the Magistra
}

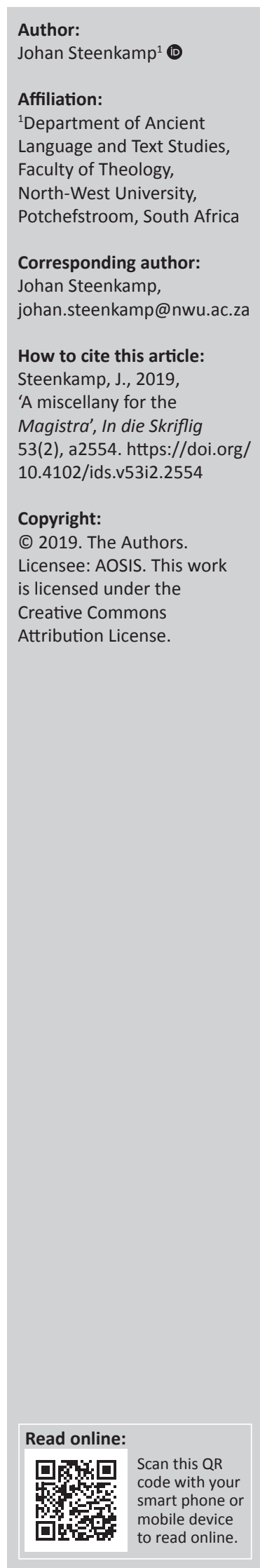

This Festschrift is dedicated to Prof. Marianne Dircksen who retired from the Faculty of Theology at the North-West University in 2016.

Prof. Marianne Dircksen is a Classicist by training, but during the course of her career, her academic interest and influence have exceeded the bounds of her original disciplinary niche. Dircksen has played (and still plays) an important role in different academic fields as the contributions to this issue attest. The following articles about Roman history, classical reception studies, teaching and learning in higher education, the English Reformation and other, are all related to a greater of lesser extent to work she has done or interests she has had.

Dircksen probably left her greatest mark on her students and for this, she is well remembered. She taught Latin in higher education since 1974 - even before she had a post-graduate qualification at what was then the Rand Afrikaans University in Johannesburg - until her retirement from teaching in 2016 at the North-West University in Potchefstroom. During this time, a vast number of students passed through her Latin classes - some of which have contributed to this Festschrift.

It is all too common in the current academic climate to regard excellence teaching as somehow a lesser academic pursuit. However, in the humanities, the students of which progress to fulfil a great variety of different roles in society, the importance of developing a critical awareness of one's society and its cultures, the inculcation of sympathy for fellow human beings, and the fostering of an appreciation for what it means to be human, is arguably of much greater value than producing graduates that have merely been adequately prepared to perform a technical function during office hours. Dircksen was keenly aware of her responsibility and worked tirelessly throughout her career to improve and update teaching methods in ancient languages and beyond. She was not only innovative in her own classroom, but contributed much of her time to serve other faculties at her own and at other South African Universities. She served continually on institutional and professional committees at the North-West University for teaching and learning, and performed the often thankless, but inevitably necessary administrative duties of a manager and school director. She also served as a moderator, critical reader and quality assurance consultant for institutions around South Africa almost every year of her career.

As teacher, Dircksen was able and willing to continuously try to improve the way in which Latin is taught and learned. Her sometimes peculiar, but often award-winning teaching methods became legendary at the North-West University, and the theoretical bases upon which these methods were conceived, have produced several published articles. This Festschrift naturally also contains several contributions on the teaching of Latin, inspired and if not in each case, based upon the work she has done. Dr Allison Geduld, one of Dircksen's former students and now a lecturer at the Faculty of Law at the North-West University, contributed the article 'Teaching Latin to law students in the midst of the decolonisation of the university curriculum', which picks up on a debate initiated by Dircksen's 'Latyn in die opleiding van regstudente in SA in die 21ste eeu: ' $n$ Nuwe relevansie', published in 2010 in De Iure and 'Reassessing Latin pedagogy: A proposed model for South African learners' in the Akroterion of 2016. Inspired by the same regard for the value of teaching Latin is Dr Koos Kritzinger's 'Teaching and illustrating the exegetical method of St Jerome: Letter 21 as a case study'. Dr Isabella Bonati's contribution, 'Latin learning materials in the light of the papyri', considers the unique context in which Latin was taught for law students in South Africa, and compares it to the context in which Latin was taught and learned in Roman Egypt 2000 years ago.

Teaching was, however, not Dircksen's first research undertaking. She started her academic career as a Roman historian with a special focus on Tacitus. Roman history has remained and still remains within her sphere of research. In the late 1980s and early 1990s, when Latin was still taught to hundreds of law students, Tacitus was an unlikely topic, but as time would tell, an important one. Dircksen worked on Tacitus from a literary perspective - especially with 
narratological approaches, which were then very new. This impression that history and literature in the ancient world did not, in fact, constitute different genres in our sense of the word and that the theoretical apparatus used to unlock the meaning of literary texts can be used to analyse historical texts, proved to be correct. During the same time, Tony Woodman, the great Tacitean scholar, used the same methods to change the way in which we read Roman historical texts and understand Roman historiography.

Dircksen's chief interest in Roman history concerned characterisation - especially of Augustus, Tiberius and important women such as Livia and Agrippina Minor. In history, such people are conventionally called persons, but if our historical texts are read as literature, they also exist as characters. It is in this grey area between history as the past and history as a consensus of narratives about the past where the problems of interpretation lie.

This Festschrift contains four contributions on Roman historical characters or persons and their reception. Prof. Jo-Marie Claassen's 'Auto-memorialisation: Augustus' Res Gestae as slanted narrative' discusses just such a characterisation of a historical person - Augustus Caesar - in a propagandistic narrative masquerading as a history. The article, which reads the Res Gestae with a narratological toolset, also considers the Res Gestae through the critical eyes of Ovid's poetry of exile and tries to recover the literary character of Augustus through an early reception of this constructed character. The contribution by Dr Steenkamp, likewise, aims to recover a literary construction of Rome's first emperor. 'Augustus Scriptus: Referencing the "real" in Propertius' turns to the late 3rd and early 2nd decade BCE, and approaches the problem through a content analysis of the poems of Propertius. This early in the transition between Republic and Empire, the image Augustus projected of himself was still unclear, but as the article maintains, some glimpses of the general attitude, shared by Rome's elite, may be gleaned through the poetry of Propertius.

The historical section also includes two articles on the reception of historical persons in modern times. Prof. Betine van Zyl Smit's contribution, 'Agrippina as prima donna: The reception of Agrippina, mother of Nero, in Handel's opera Agrippina', demonstrates how ancient Roman histories were received by 18th century opera as literary productions, and turned into dramatic narratives for music and stage. At once similar and completely different is the contribution by Drs Nelson Bondioli, Marcio Texeira-Bastos and Luciano Caetano Carneiro. Their article, 'History, design and archaeology: The reception of Julius Caesar and the representation of gender and agency in Assassin's Creed Origins', considers the reception of Roman history in the very latest literary genre of the 21st century - the videogame. New and daring as the topic of reception in popular culture is, the analysis is based on the now established avenues of gender studies and post-colonialist theory.

Since her retirement from permanent faculty in 2016, Dircksen has embarked upon what can be called a third academic career. Teaming up with Prof. Victor Houliston from the University of the Witwatersrand, she is contributing to a project on the writings of the early English Jesuit leader, Robert Persons (1546-1610), an important and much-neglected figure in the English Reformation. The project's most immediate aim is to publish a critical edition of Persons' De Persecutione Anglicana in 2020. Houliston has also contributed to this Festschrift with 'Puzzles and posts: Reconstructing Robert Persons' correspondence with Claudio Acquaviva, 1589-1592'. Although this article is concerned with only a tiny part of Persons' history, it represents an important part of the research in which Dircksen is currently partaking.

The final section represents articles from some of the diverse fields Dircksen passed through during her long career. Her curiosity and appetite have, at times, lead her far from the field of Classics, but has also influenced many colleagues from other disciplines. Some of these have graciously contributed to this Festschrift.

Latin, along with other ancient languages, is housed in the Faculty of Theology at the North-West University and it is little wonder that Dircksen also has longstanding relationships with theologians. This issue contains two theological contributions: Dr Elma Cornelius's 'The obsession with greatness leads to power abuse: Is spiritual intelligence an appropriate response?' and Prof. Robin Gallaher Branch's 'Female leadership as demonstrated by Phoebe: An interpretation of Paul's words introducing Phoebe to the saints in Rome'.

Lastly, but certainly not least, is a contribution on Hellenistic poetry by emeritus Prof. Bill Henderson. Henderson has been a lecturer, mentor and colleague of Dircksen since the late 1970s and have (with A.F. Basson) co-authored Dircksen's first publication related to Latin teaching, the textbook Lingua Latina, published in 1991 in Johannesburg. His contribution in this issue, 'Some more ways to die: Accidental deaths in Hellenistic epigrams', is based on research done for a translation and commentary on Hellenistic poetry, which was published in three volumes by Imprimatur in 2019 .

Although it is impossible to do justice to such a career and such an academic life in an introduction, it is hoped that this Festschrift will give some glimpse into the world in which Prof. Dircksen spent her academic career and afford some pleasure to the people who knew her and knew of her. It remains for me to thank her personally and on behalf of all her colleagues and students for the inspiration, friendship and academic guidance, and to wish her all the best for the future. 